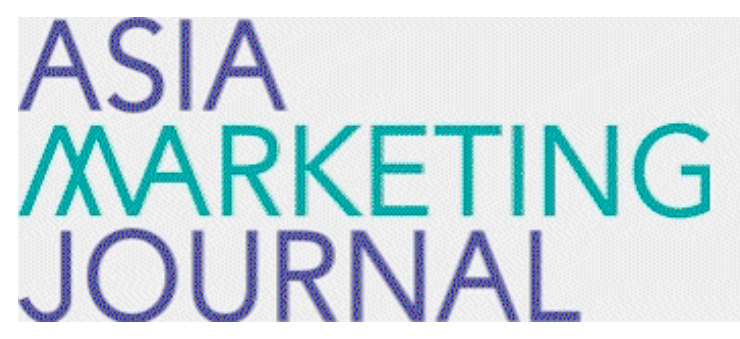

ASIA MARKETING JOURNAL

Volume 2 | Issue 1

Article 1

$3-1-2000$

\title{
브랜드 수준과 카테고리 수준에서의 상황적 경쟁 구조에 관한 연구
}

Young June Kim

So Young Kim

Follow this and additional works at: https://amj.kma.re.kr/journal

Part of the Marketing Commons

\section{Recommended Citation}

Kim, Young June and Kim, So Young (2000) "브랜드 수준 과 카테고리 수준에서의 상활적 경쟁 구조에 관한 연 구," Asia Marketing Journal: Vol. 2 : Iss. 1 , Article 1.

Available at: https://doi.org/10.53728/2765-6500.1029

This Article is brought to you for free and open access by Asia Marketing Journal. It has been accepted for inclusion in Asia Marketing Journal by an authorized editor of Asia Marketing Journal. 


\title{
브랬드 수준과 카테고리 수준에서의 상황적 경쟁 구조에 관한 연구*
}

\section{The Study on Situational Market Structure in Brand-Level and Category-Level}

\author{
김 용준 (성균관대학교 경영학부 교수) \\ kimyjeyurim.skku.ac.kr \\ 김 소영 (성균관대학교 경영연구소 전임연구원) \\ sykimedragon.skku.ac.kr
}

기업환경의 변화로 인하여 정확한 경쟁구조의 파악은 경쟁전략의 수립에 중요한 개녑으로 대두되고 있다. 본 연구에서는 소비자중심의 경쟁구조 파악의 중요성을 제기하고 그 일환 으로 상황 변수를 고러한 경쟁 구조 분석의 펄요성을 제시하고 있다. 또한 구체적인 상황 변수률 파악하기 위한 방법으로 카테고리 수준에서의 경쟁 구조 분석을 제기하고 있다. 이 를 위해 음료수 시장을 대상으로 브랜드 수준과 카테고리 수준에서의 지각적 및 상황적 경 쟁 구조 분석을 실시하여 그 결과를 비교하였다. 분석 결과, 브랬드 수준에서는 지각적 경 쟁구조와 상황적 경쟁구조가 상이하게 나타났고 카테고리 수준에서는 두 경쟁 구조가 상당 히 유사한 것으로 나타났다. 이를 통해 소비자들온 음료수 구매와 관련하여 '소비(음용) 상황이라는 기준에 의해 음료수 제품들을 법주화하는, 즉 소비자돌의 기억속에 옴용 상황 이라는 기준에 의한 스키마가 형성되어 있다고 볼 수 있는 근거를 제시하였다. 카테고리 수준에서의 경쟁 구조 분석을 통하여 마케터는 소비자의 구매행동과 관련한 중요한 상황 변 수를 파악할 수 있고, 이렇계 파악된 상항 변수률 토대로 한 경쟁 구조 분석을 실시함으로 써 보다 소비자 중심적이며, 안정적인 시장 경쟁 구조의 파악이 가능하다고 본다.

\footnotetext{
논문접수:99.12 게재확정 00.1
}

* 이 연구는 1997 년도 한국학술진흥재단의 학술연구비에 의하여 지원되었음. 


\section{1. 서 른}

시장규모의 성장속도가 둔화되면서 기업간의 경쟁온 심화되어 가고 있다. 소비자의 역량 이 성장함에 따라, 점점 더 '고객중심의 마케팅'이 대두되었으며, 대중마케팅에서 '표적마케 팅'으로의 전환이 요구되고 있다. 이러한 흐름에 따라 정확한 경쟁 구조의 과악이 경쟁전략 수립에서 중요한 개념으로 떠오르고 있다. 경쟁 구조 분석의 중요성은 경쟁 구조가 어떻게 정의되고 있는가에 따라 시장의 크기가 달라질 뿐만 아니라 목표시장도 달라지고 따라서 마 케팅 경쟁전략 또한 달라지게 된다는 데 있다.

이처럽 경쟁전략 수립에서 기초가 되는 시장의 경쟁 구조 분석 방법으로는 공급자 중심 의 전통적인 방법과 소비자률 중심으로 경쟁 구조률 분석하는 방법이 있다. 시장을 제품중 심적으로 파악하는 전통적인 경쟁 구조 분석방법은 소비자가 인지하고 있는 실제 경쟁 구조 률 정확히 표현하기 어렵다는 한계점을 가지고 있다(Day, Shocker, and Srivastava 1979 ; Czepiel 1992). 따라서 경쟁 구조 분석욜 통해 효과적인 마케팅 전략을 수립하기 위해서는 보다 의 미있는 경쟁 구조률 재공해 줄 수 있는 방법이 요구된다. 이러한 점에서 최근 관심을 모으 는 연구방향온 재품중심의 경쟁 구조가 아니라 “소비자 중심의 경쟁 구조"이다. 즉 소비자 의 관점에서 자사제품과 직접 또는 간접적으로 경쟁하는 제품들이 무엇인지를 파악하고 이 에 따라서 자사제품의 시장영역을 명학히 졀정하여 효율적인 마케팅 전략을 수립할 수 있는 근거를 제공해 주는 것이다.

소비자가 제품을 구입할 때는 제품 그 자체률 구입하는 것이 아니라 그 제품에서 얻을 수 있는 편익(benefit)을 구입하는 것이라는 점에서, 우리는 소비자가 제품소비에서 추구하 는 편익은 언제나 일정한 것이 아니라 그 제품율 사용하는 상황(situation)에 따라 달라진다 는 점을 간과해서는 안둴 것이다. 이것이 바로 경쟁 구조 분석에서 상황 변수가 중요성을 가지는 이유인 것이다(이학식 안광 호 -하영원 1999). 이처럽 상황 변수는 소비자선택을 설 명하기 위해서 개인적인 변수듈과 함께 반드시 고려되어져야 하는 중요한 변수이며, 행동관 련 변수들보다 소비자 구매행둥의 더 많은 분산을 설명하는 중요한 것이다(Engel, Blackwell \& Miniard 1995). 따라서 소비자가 인지하고 있는 실제 경쟁 구조를 파악하기 위해서는 상 황 변수률 고려한 경쟁 구조 분석이 필요하며, 여기서 소비자가 인지하고 있는 정확한 경쟁 구조률 형성하는데 중심이 되는 상황 변수는 구체적으로 어떤 것인가의 파악이 필요하게 된 다.

이롤 위해 본 연구에서는 기존의 대부분 경쟁 구조 연구들(박세훈 1995 , 하영원 박훙수 1992, 한상만 길 소영 1997)이 브랜드 수준에서 경쟁 구조률 파악하는 것과는 달리 카테고 리 수준에서도 경쟁 구조룰 파악하고자 한다. 이렿게 카테고리 수준에서 소비자들의 지각 적 경쟁 구조폴 분석하세 되면 보렌드 수준에서의 치각적 경쟁 구조 분석 결과에서 나타나 
는 제품들의 물리적 속성이라는 기준에 의한 경쟁 구조와는 달리, 소비자들의 구매경험으로 부터 장기 기억 구조 속에 이미 형성되어 있는 해당 제품들과 관련한 가장 친숙한 기준에 의한 경쟁 구조가 그려질 것이고, 이러한 범주화 기준(categorization cue)이 무엇인지률 알게 되면 소비자들이 해당 제품군과 관련하여 가장 친숙하고 장기 기억 속에 잘 확립되어 있는 인지구조, 즉 스키마(schema)에 관한 정보를 얻을 수 있게 된다. 이러한 기준(cue)과 스키마 의 파악은 소비자가 인지하고 있는 실제 경쟁 구조를 형성하는 데 중심이 되는 구체적인 상 황 변수가 무엇인지률 알 수 있게 하며 이는 어떤 상황적 변수률 중심으로 경쟁 구조 분석 이 이루어져야 되는가에 대한 정보률 제공해준다. 즉, 상황 변수는 소비상황, 구매상황, 그 리고 커뮤니케이션 상항으로 분류되는데(Bearen \& Woodside, 1978) 상황적 경쟁 구조의 분석 에 있어서 해당 제품시장에 대한 소비자들의 인지 속에 어떠한 구체적인 상항 변수에 의한 스키마, 즉 경쟁 구조가 그려져 있는지를 파악해야 하며 이러한 cue를 토대로 한 경쟁 구조 분석이 보다 정확하고 안정적인 경쟁 구조의 파악을 가능하게 할 것이다.

또한 카테고리 수준의 경쟁 구조 분석은 출시되는 신제품의 혁신성이 높을 경우 신제품 이 기존의 어떤 제품군과 경쟁을 하게 될 것인지를 파악하고자 할 때에 유용한 정보률 제공 한다. 예를 듈어, 카페라뗘가 처음 시장에 출시되었을 때 제품의 혁신성으로 인해 이 제품이 커피군과 경쟁하는지 아니면 우유군과 경쟁하는 것인지 알기가 어려욌다. 이 경우 브랜드 수준에서의 지각적 경쟁 구조 분석은 물리적 속성의 유사성에 의한 경쟁 구조를 나타내는 반면 카테고리 수준에서의 지각적 경쟁 구조 분석은 소비자들의 인지 속에 실제 경쟁하는 제품군이 어떤 것인지에 대한 즉, 해당제품의 진정한 경쟁자률 파악하는데 도움을 줄 것이 다.

이상의 논의를 위해 본 연구에서는 크게 두 가지의 가설을 설정하였다. 첫째, 상황적 경 쟁 구조 분석의 필요성을 제기하기 위하여 기존 연구들과 마찬가지로 브랜드 수준에서의 음 료수시장의 지각적 경쟁 구조와 상황적 경쟁 구조 분석을 비교한다. 여기서는 두 경쟁 구 조간 차이가 발생할 것이라는 가설을 설정하였으며, 이는 브랜드 수준에서 범주화 과업을 수행합에 있어 가장 친숙하면서도 인지적 노력을 덜 들이는 범주화 기준으로 지각적 경쟁 구조에서는 물리적 속성이라는 기준을 사용하였을 것이며, 상황적 경쟁 구조에서는 주어진 기준인 상황이라는 법주화 기준을 토대로 범주화 과업을 실시할 것이라는 점을 토대로 한 것이다. 비교결과 두 경쟁 구조가 상이하다면 이는 보다 소비자중심의 경쟁 구조파악이라 는 측면에서 상황적 경쟁 구조 분석의 필요성을 주장할 수 있게된다. 그러나 이 상태로는 상황적 변수 중 구체적으로 어떤 상황 변수가 해당제품에 있어서 소비자들의 장기 기역속에 구조화되어있는 경쟁 구조인지에 대한 정보를 제공해 주지는 못한다. 따라서 다음의 연구 과제가 펄요하다. 둘째, 카테고리 수준에서 지각적 경쟁 구조와 상황적 경쟁 구조를 비교한 다. 여기서는 카테고리 수준에시의 지각적 경쟁 구조와 상황적 경쟁 구조가 유사할 것이라 
는 가설을 검중한다. 만약 카테고리 수준에서의 두 경쟁 구조가 유사하다면 이는 카테고리 수준에서는 브랜드 수준과는 달리 소비자듈이 범주화 과업을 수행함에 있어 제품들간 물리 적 유사성이라는 기준을 사용하기가 어렵기에 가장 친숙하면서도 인지적 노력을 덜 들이는 범주화 기준으로 지각적 경쟁 구조에서 상황이라는 기준을 사용한 것이며, 상황적 경쟁 구 조에서는 브랜드 수준에서와 마찬가지로 주어진 기준인 상황을 토대로 하여 범주화 과업을 수행한 것이라고 보는 것이다. 물론 상황적 경쟁 구조 분석에서는 구체적으로 특정 상황 변수를 제시하고 있기에 두 경쟁 구조가 유사하다는 것은 카테고리 수준의 지각적 경쟁 구 조에서 소비자들이 상황적 경쟁 구조와 동일한 톡정 상황 변수률 기준으로 하여 범주화 과 업을 실시한 것이라고 볼 수 있는 것이다. 이를 퉁해 소비자들의 구매경험으로부터 장기 기억 구조 속에 이미 형성되어 있는 해당제품과 관련한 가장 친숙하고 잘 확립되어 있는 인 지구조, 즉 스키마에 관한 정보률 흭독할 수 있으며, 해당제품과 관련하여 구체적으로 어떤 상황적 변수를 중심으로 상황적 경쟁 구조를 분석하여야 하는지에 대한 유용한 정보도 얻을 수 있다.

\section{2. 이른적 배경}

\section{1. 경쟁 구조 분석의 의미}

Day, Shocker, and Srivastava(1979)는 제품시장을 “톡정한 상황에 특정한 소비자집단에 의해 대체 제품으로 인식되는 제품군"이라고 정의하고, Srivastava, Alpert, and Shocker(1984)는 “소비 자 집단이 효용의 유사한 형태를 찾는 사용상황내에서 대체될 수 있는 제품의 집합체"라고 정의하였다. 따라서, 경쟁 구조 분석은 “상호관계가 명백한 일련의 제품(또는 브랜드)을 묶 기 위한 과정"이라 할 수 있다(Grover and Dillon 1985).

경쟁 구조률 분석하는 이유는 경쟁 구조률 어떻게 정의하는가에 따라 시장의 크기가 전 혀 달라질 뿐만 아니라 목표시장도 달라지고, 경쟁의 상태도 달라지기 때문이다. 그리고 하 나의 커다란 시장을 여러 측면에서 세분화시킬 수 있는데 하부시장으로 갈수록 경쟁의 강도 가 치열해지기 때문에 정확한 하부시장에서의 경쟁자률 파악하는 것이 무엇보다도 중요하다 고 할 것이다. 즉, 경쟁 구조 분석을 퉁한 제품시장의 정의는 새로운 제품이 속해 있는 시 장의 크기를 확정하는데 결정적인 역할율 하며, 시장을 어떻게 정의하는가에 따라 시장에서 의 경쟁상태가 달라진다. 그리고 시장에서 신제품의 경쟁상대가 어떤 제품인가에 따라 자기 잠식성(cannibalization)의 정도가 달라진다. 
경쟁적 시장 구조에 대한 정확한 이해는 기업의 마케팅 관리자들에게 제품전략을 평가할 때도 중요하다. 즉 시장을 어떻게 보느냐에 따라 경쟁제품에 대한 시장에서의 전략이 달라 질 수 있는 것이다. 마케팅 관리자는 신제품의 출하, 제품의 재구성, 포지셔닝 결정에 있어 경쟁자가 무엇에 의해 영향을 받고, 또 무엇에 의해 가장 민감하게 반웅할 것인지를 알려는 욕구가 있다. 이러한 욕구는 경쟁적 경쟁 구조를 분석함으로써 충족될 수 있는 것이다 (Urban, Johnson, and Hauser 1984)

\section{2. 상황 변수와 경쟁 구조}

상황 변수는 직접적으로 행동에 영향을 미칠 뿐 아니라 제품 및 개인적 특성과의 상호작 용을 통하여 소비자 행동에 영향을 미친다. Engel, Blackwell and Miniard(1995)는 구매행위자 와 관련된 변수들보다 상황 변수들이 변화를 더 잘 설명할 수 있다고 했으며 개인과 상황 변수를 동시에 고려하여 소비자 선택을 설명해야 한다고 말하고 있다. 또한 Ward \& Robertson(1973)은 상황 변수는 행동관련 변수들보다 소비자구매행동의 더 많은 분산을 설명 한다고 했다. 소비자는 특정한 구매관련 상황 하에서 구매를 한다. 가령 소비자에게 자신 이 구매하는 음료수상표나 커피상표에 대해 질문하면, 언제, 어디서, 어떻게 사용하느냐에 따라 구매하는 상표가 달라질 수 있다. 소비자는 <식사 후 마시는> 옴료수와 <운동 후 마 시는> 옴료수가 다를 수 있으며, <혼자서 마실 때> 선호하는 커피상표와 <손님접대나 선물 용>으로 구매하는 커피상표가 다률 수 있다. 사용상황은 소비자의 상표에 대한 지각, 선호 및 구매행동에 직접적인 영향을 미친다.

상황은 크게 소비상황, 구매상황, 커뮤니케이션 상황으로 분류된다(Bearen \& Woodside, 1978).

\subsection{1 소비상황}

소비상황은 소비자가 제품을 사용하는 과정에서 영향을 미치는 환경 내 사회적 및 물리적 요인들을 말한다. 소비자가 손님접대률 위해 원두커피률 구매하고, 혼자 마시기 위해서는 즉석커피를 구매할 수 있다. Bearen \& Woodside(1978)는 가까운 친구와 집에서 즐거운 시간 올 보내면서, 주말 밤에 레스토랑에 가서, 스포츠나 줗아하는 TV프로를 보면서, 스포츠나 취미활동을 하면서, 주말여행을 하면서, 정원, 집에서 작업을 하면서, 집에서 휴식을 취하면 서 등과 같은 다양한 맥주 소비상황을 발견하였다. 이는 각 소비상황마다 상이한 맥주경쟁 구조가 파악될 수 있옴을 암시하는 것이다. 


\subsection{2 구매상황}

구매상황은 구매과정에서 영향을 미치는 환경 요인들을 말한다. 중요한 구매관련 상황은 점포 내 환경(가격변화, 판촉 둥), 구매목적(자기사용 혹은 선물용), 구매시점에서의 소비자 의 기분상태, 예기치 않은 사태의 발생(재고소진, 불량제품) 둥을 포함한다. 제품이 선물용 으로 또는 자기소비를 위해 구매하느냐는 소비자의 구매행동에 영향을 미치는 구매관련 상 황의 하나이다.

\subsection{3 커뮤니케이션상황}

커뮤니케이션상황은 제품정보에 노출될 때의 주변 배경이다. 이는 대인간 접촉(친구들 간 구전 커뮤니케이션) 또는 비인적 접촉(광고, 점포내 디스풀레이)상황으로 구분할 수 있으 며, 이러한 상황 변수는 광고효과에 직접적인 영향을 미칠 것이다.

\section{3. 인지적 정보처리과정과 경쟁 구조 분석}

사랍들을 둘러싸고 있는 환경에 대하여 효과적인 이해와 효율적인 정보처리를 할 수 있도 록 자연스러운 범주(category)률 형성한다고 심리학의 연구들은 밝히고 있다(Rosch 1978 ; Rosch and Mervis 1975). 즉, 어떤 사물들의 집합을 인식할 때, 이듈의 특성을 체계적인 하위 범주들로 묶음으로써 쉽게 파악하려 한다는 것이다. 마찬가지로 소비자들도 하위시장으로 체계화된 경쟁 구조률 인식하여 상품대안을 싑게 파악하고 의사결정을 편리하게 하려는 경 향이 있다. 족, 상품의 선택대안집합을 형성할 때 소비자들은 선택하려는 여러 상품들을 관 련된 상품내지 상표끼리 같은 범주로 결합함으로써 의사결정을 단순화하려는 범주화 (categorization) 노력을 한다는 것이다(Alba and Hutchinson 1987; Brucks 1986; Nedungadi and Hutchinson 1985). 자극대상(예, 제품, 소비자 둥)들을 차별화 하기 위해 범주 구조(Category Structure)를 사용하는 것은 심리학이나 소비자연구에서 자주 이용되었다. Alba \& Hutchinson(1987)은 제품군, 편익세분화, 사용상황 및 환기상표군과 같온 마케팅 개념들은 경 쟁하는 상표들에 대한 일종의 범주구조화를 실시한 예라고 하였다.

Marlatt(1995)에 의하면 자극범주화(stimulus categorization)는 소비자의 기억 속에 저장되어 있는 개념들을 사용해서 자극을 분류해내는 작업이고, 이때 기억 속에 저장되어 있는 개념 들이 인출되기 위해서는 'cue', 즉 실마리 또는 기준이 필요하며, 인출은 활성화되는 당시에 제시되는 기준에 의해 보다 중진된다고 한다. 또한 이러한 기준은 자생적으로 생겨나기도 하지만 외적으로 만들어지기도 한다. 이때 소비자들은 사고의 효율성이라는 논리를 바탕으 로 가장 적절한 기준을 찾아내게 된다. 즉, 주어진 과업의 최적화와 과업 수행에 드는 비용 
의 상쇄관계를 고려해 볼 때 사람들은 기준이 주어져 있으면 이 기준대로 기억 속의 정보들 을 이용하여 자극들을 범주화하는 것이 가장 효율적일 것이다. 반면 기준이 주어지지 않을 경우, 소비자들은 가장 적절한 기준을 이용하여 자극들을 재구성할텐데, 이때에도 사고의 효 율성이라는 측면이 고려된다. 따라서 어떤 기준올 갖고 제품들을 범주화할 때 머리 속에 저 장되어 있는 기존 스키마(schema)률 토대로 최적의 범주화가 이루어질 것인지를 판단하게 된다. Park \& Lessig(1981)에 의하면 친숙도가 낮으면 잘 확립된 지식구조가 없기 때문에 자 극판혈이 어려우며, 친숙도가 높으면 잘 확립된 지식구조에 의해 자극판별이 쉬워진다고 하 였다. 여기서 자극들을 범주화함에 있어 자극들과 관련해서 소비자에게 가장 친숙한 기준 이 범주화의 기준으로 사용될 것이라고 예측할 수 있다. 이러한 논의률 토대로 제품대안들 의 유사성올 퉁해 경쟁 구조를 파악하게 되는 지각적 경쟁 구조는 소비자들에게 가장 친숙 한 기준을 이용하여 자극대안들을 범주화하게 둴 것이다. 즉, 상기되는 기준은 자생적으로 만들어질 것이다. 반면 구매상황을 주고 제품듈의 구매의도률 평가하도록 하는 상황적 경쟁 구조는 외적으로 만들어진 기준 즉, 과업에서 이미 제시된 기준을 이용해서 기억속에 저장 되어 있는 자극들과 관련한 개념을 사용해서 자극들을 재구성하는 것이 사고의 효율성 측면 에서 가장 효율적일 것이다. 따라서 상황이라는 기준이 주어지면 이를 이용하여 자극둘을 범주할 것이다.

\section{3. 가설설정}

\section{1. 브랜드 수준에서의 지각-상황 경쟁 구조 분석}

앞장에서 언급한 소비자의 인지적 정보처리과정올 토대로 하면, 브랜드 수준에서 상표들 간의 유사성평가에 대해서 소비자들은 사고의 효율성을 고려하여 가장 친숙하면서도 상표 대안듈을 최적으로 분류할 수 있게 해주는 기준을 찾게 된다. 즉, 범주화의 기준을 외부에 서 찾아 이를 이용해서 기억 속에 저장되어 있는 자극들과 관련한 스키마를 토대로 자극들 을 범주화하게 될 것이다. 이때 범주화의 한 유형인 '기본적 수준의 범주'를 이용할 것이다. Rosche(1978)에 의하면 개인은 특별한 자극환경이 주어지지 않는다면 자연스럽게 대상들을 ' 기본적인 수준'으로 범주화하려 하는데, 이는 특정 범주에 해당하는 구성 요소들의 독특한 톡성들이 다른 범주의 구성 요소들에 의해 공유되는 속성들과는 다르게 되는 비율을 극대화 하는 방향으로 범주화하는 것이라고 하였다. 이러한 한 예로서 Sujan \& Dekleva(1987)는 음료 수 제품을 범주화 할 때 사람들이 청량음료, 과일쥬스 둥과 같이 제품들을 분류하는 것도 이러한 기본적인 수준에서의 대상들에 대한 범주화라고 설명하고 있다. 즉, 음료수의 경우 
소비자들이 제품간 차이률 가장 잘 나타내주는 물리적 속성을 토대로 탄산음료, 과즙음료, 이온음료 둥과 같은 범주화인 기본적 수준의 범주(basic level object category)에 의해 지각적 범주화률 수행하게 될 것이라는 것이다. 이는 소비자들은 범주화률 할 때 제품의 속성들이 화기되는 제품 범주와 일치하거나 잘 조화률 이률 때 인지적 자원을 덜 사용하게 된다는 Mayers-Levy \& Tybout (1989)의 주장과도 일치하는 것이다. 즉, 어떤 제품이 탄산음료와 더 잘 부합될 때, 범주화는 덜 자원을 필요로 하게 되지만 어떤 제품이 탄산음료 범주와 잘 부 합되지 않을 때는 범주화에 더 많은 인지적 노력이 필요하게 된다. 따라서 웅답자는 인지 적 노력을 덜 기울이고도 적절한 범주화 과업을 수행하려 할 것이기에 제시되는 제품들과 잘 부합되는 기준을 선정하게 둴 것이고 이 기준은 바로 기억 속의 인지적 구조인 스키마를 토대로 지각적 범주화률 실시하도록 할 것이다. 코카콜라, 펩시콜라, 게토레이, 포카리스웨 트 둥과 같은 상표들이 제시될 경우에는 제품의 속성들이 환기되는 제품 범주와 친숙하여 인지적 노력을 덜 기울이고도 쉅게 적절한 조화를 이률 수 있는 탄산음료, 이온음료로의 범 주화률 생각하게 될 것이라 본다. 동일 제품군내 여러 가지 상표대안들이 제시되고 이들의 유사성을 판단하게 되는 지각적 경쟁 구조는 가장 인지적 노력을 덜 기울이면서도 적절한 조화률 이률 수 있는 재패매안의 마리적 속헝이라는 기준(cue)을 토대로 지각적 범주화할 것이라고 예상해볼 수 있다.

다음으로 상황적 경쟁 구조틀 파악하가 위해 상황별 제품 대안들의 평가를 퉁한 범주화에 서는 소비자들이 수행해야 하는 과업에 미리 기준을 제공해주고 이를 토대로 자극들을 평가 하도록 한다. 따라서 지각적 경쟁 구조에서와 같이 자체적으로 기준을 만들어낼 필요 없이, 이미 주어져 있는 기준을 이용하는 것이 사고의 효율성을 가장 잘 충족시킬 수 있을 것이다. 즉, 상황별 제품들의 구매의도률 질문하여 경쟁 구조를 파악하려는 상황적 경쟁 구조 분석 의 경우는 소비자들이 인지적 노력을 덜 기울이면서도 적절한 범주화 과업을 수행하기 위한 기준을 선정할 때 바로 자극환경에서 이미 제시되어 있는 '상황'이라는 기준을 이용하여 범 주화할 것이다. 예를들어 '갈중상황'이 주어지면 소비자들은 머리 속에 이미 형성되어 있는 사용상황 스키마률 중심으로 상표들을 해석하게 됨으로써, 물리적 속성이 다른 게토레이나 코카콜라가 동일한 하나의 범주률 형성할 수 있게 된다. 음료수시장에서 상표들간 물리적 속성으로 이를 토대로 지각적 범주화를 하게 되는 지각적 경쟁 구조와는 달리 옴용 상황에 의한 상황적 경쟁 구조는 상황이라는 기준과 관련한 스키마와 제품들을 관련지움으로써 제 품들을 평가하게 된다.

따라서 제품들의 공통된 객관적 속성의 유사성에 의해 기본적인 수준에서 범주화 되는 지 각적 경쟁 구조와 상황뼐 제품들의 구매의도를 평가하도록 하는 상황적 경쟁 구조의 형태는 상이할 것이라고 볼 수 있다. 이상의 논의를 토대로 본 연구에서는 다음과 같은 가설 1 을 제시하고 있다. 


\section{영구가선 1:}

\section{브램드 수준에서는 지각정 경징 구조와 상항적 경젱 구조가 상이한 것이다.}

\section{2. 카테고리 수준에서의 지각-상황 경쟁 구조 분석}

카테고리 수준에서는 제품 카테고리를 대표하는 하나의 상표률 선정하여 그 상표 대안들 에 대한 유사성평가를 하는 지각적 경쟁 구조와 상황별 구매의도를 묻는 상황적 경쟁 구조 률 분석하였다. 우선, 카테고리 수준에 있어 지각적 경쟁 구조 분석에서는 앞의 상표수준에 서의 경우와는 달리 '기본적 수준의 범주화'는 어렵다.고 볼 수 있다. 왜냐하면 각 제품군마 다 하나의 대표적인 상표들을 제시하고 있기에 특정 범주에 해당하는 구성 요소들의 독특한 특성들이 다른 범주의 구성 요소들에 의해 공유되는 속성들과는 다르게 되는 비율을 극대화 하는 방향으로 이루어지는 기본적 범주화는 어렵다. 따라서 소비자들은 다른 기준을 찾아 야 하는데 이때에도 주어진 자극들을 가장 잘 판별해낼 수 있으면서 가장 인지적 노력이 덜 드는 기준을 사용하려 할 것이다. 여기서는 소비자돌의 음료수 구매경험둥과 관련하여 가 장 높은 친숙도률 나타내는 기준이 선정될 것이다. 이는 친숙도가 낮으면 잘 확립된 지식 구조가 없기 때문에 자극판별이 어려우며, 친숙도가 높으면 잘 확립된 지식구조에 의해 자 극판별이 쉬워진다(Park \& Lessig, 1981)는 주장에 근거한 것이다. 예를 들어, 자극들을 판 별하기 위해 '음용 상항'이라는 기준을 선정했다면 <운동 후 상황> 에서는 게토레이, 코카 콜라가 그리고 <손넘접대 상황> 에서는 과일쥬스, 전통음료둥이 하나의 범주로 묵일 수 있 올 것이다. 이는 지각적 경쟁 구조에서 제품들의 공통된 물리적 속성에 의한 범주화와는 다른 결과다. 이처럼 만약 소비자들이 상표들간 유사성을 판단하는 기준으로 '상황' 변수를 이용하게 된다면, 지각적 경쟁 구조와 상황적 경쟁 구조는 일치할 것이라고 예상할 수 있다. 그렇다면 주어진 음료수 제품들과 관련하여 소비자들은 어떤 기준을 갖고 제품들을 범주화 할 것인가? 이 때 범주화의 기준이 무엇이었는지를 파악할 수 있다면 우리는 소비자들이 해 당제품군과 관련하여 가장 친숙도가 높고 잘 확립된 장기 기억 속의 인지구조, 즉 스키마에 대한 정보를 흭득할 수 있을 것이다. Sandell(1968)의 개인과 상황 변수간 상호작용에 대한 연구를 보면 상황을 제품과 독립적인 상황과 제품에 종속된 상황으로 구분하여 설명하고 있 는데, 제품과 독립적인 상황이란 제품 대안과 관계없이 소비자에게 영향을 주는 일반환경이 라고 할 수 있으며, 제품에 종속된 상황이란 특정 제품선택에 자극제가 되는 사용상황의 개 념이라고 하였다. 또한 그의 연구결과 음료수에 있어서는 개인과 소비 상황간의 상호작용이 음료수 선택에 가장 강력한 예측 도구였다. 또한 Clark \& Belk(1979)는 단일용도의 소비를 목적으로 구매되는 많은 소비용품(청량음료, 스낵제품, 맥주 둥)들의 경우 소비자가 처한 소 비상황이 소비자행동에 직접적인 영향을 미치는 것으로 나타났다. 따라서 본 연구에서는 음료수 제품들과 관련하여 소비자들은 머리 속에 소비상황, 즉 음용상황별로 잘 확립된 스 
키마률 갖고있을 것이며, 따라서 기본적 수준의 범주화가 어려운 카테고리 수준에서의 음료 수 제품 자극들에 대해 소비자들은 가장 친숙하며 인지저 노럭을 멀 들이는 기준으로 '용용 상항이라는 기준을 토매로 하여 자국들을 법주화할 것이라고 예상해볼 수 있다. 따라서 음용 상황을 중심으로 한 카테고리 수준에서의 지각적 경쟁 구조가 파악둴 것이라고 예상할 수 있다.

이러한 카테고리 수준에서의 지각적 경쟁 구조의 파악은 해당 제품들의 구매와 관련하여 소비자듈에게 가장 친숙하고 그듈의 머리 속에 잘 확립되어 있는 장기 기억 속의 스키마에 대한 중요한 정보률 제공해줄 수 있으며, 마케터는 해당 제품들의 경쟁 구조를 파악하고자 할 때에도 어떤 기준, 즉 cue가 사용되었는가률 토대로 기준별 보다 구체적인 경쟁 구조률 파악할 필요가 있는 것이다. 픅히 제품이 혁신적인 신제품일 경우에는 카테고리 수준에서 신제품이 어떤 제품군과 경쟁하는지률 파악하여야 하며, 이때 카테고리 수준에서의 지각적 경쟁 구조 파악을 통해 소비자들이 어떠한 범주화 기준을 가지고 장기 기억 속의 스키마를 형성하고 있는지에 대한 정보률 흭득할 수 있을 것이다.

다음으로 상황적 경쟁 구조를 파악하기 위해 상항별 제품 대안들의 평가를 통한 범주화에 서는 브랜드 수준에서의 논의가 그대로 적용되어 마리 주어진 상황을 기준으로 하여 제품들 을 재구성하는 범주화률 수행할 것이다. 이상의 논의대로라면 카태고리 수준에서의 지각적 경쟁 구조와 상황적 경쟁 구 조는 유사한 형태률 나타낼 것이라고 불 수 있다. 따라서 다 음과 같은 가설 2 가 제시둴 수 있다.

\section{염구가설 2:}

카태고리 수준에서는 지각정 깅젱 구조와 상항저 경중 구조가 유사할 것이다.

이상의 논의률 토대로 연구가설이 도츨되는 모형을 간단히 제시하면 <그립 1>과 같다.

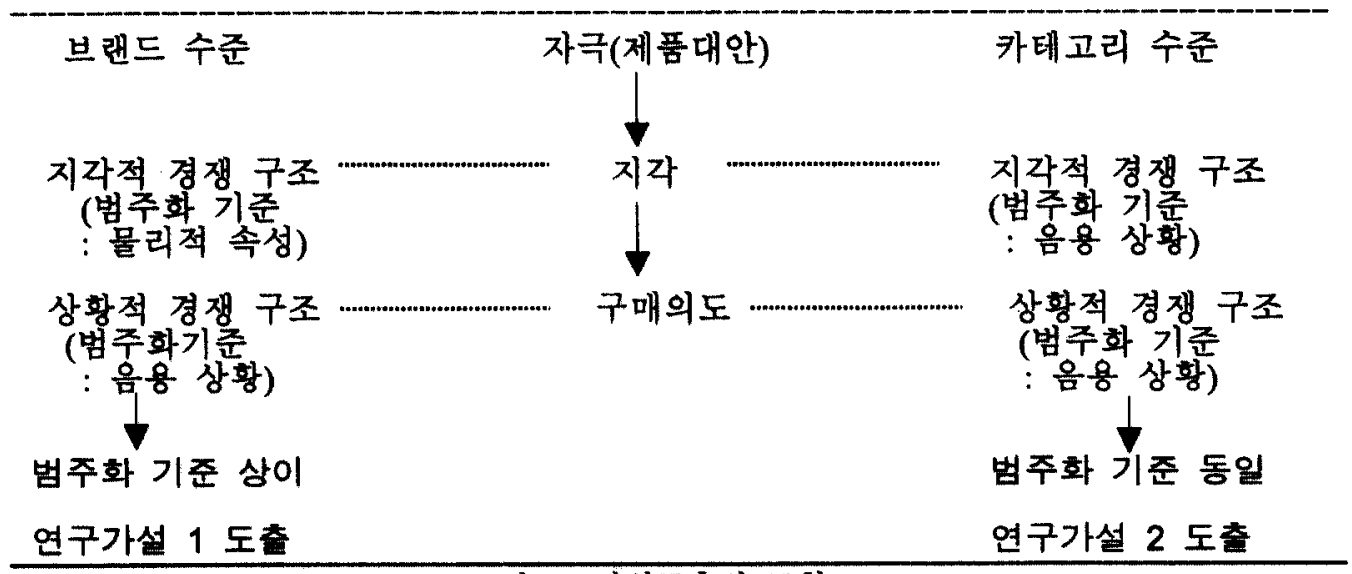




\section{4. 연구방법른}

\section{1. 연구대상}

본 연구는 서울과 수도권에 거주하고 있는 대학생들을 연구대상으로 하였으며 총 표본 은 74 명이었다. 표본추출방법은 현실적인 어려움으로 인해 편의표본추출법을 이용하였다. 설문조사는 98 년 4월 20 일부터 약 일주일간 실시되었다. 연구대상 제품은 음료시장을 선정 하였다. 옴료시장을 선정한 이유는 기존의 문헌연구를 통해 나타나는 공통적인 특징인 시 장의 규모가 크고 연구대상이 되는 대학생들에게 친숙한 제품군이며(Ratneshwar and Shocker 1991), 시장이 넓게 정의되어 있고 시장의 환경이 급속히 변화하고, 제품 혹은 브랬드의 경 쟁이 증가하여 대체의 가능성이 높은 시장이기 때문이다(Srivastava, Leone, and Shocker 1981; Srivastava, Alpert, and Shocker 1984). 특히 음료와 관련하여 음료시장의 환경을 가능한 많이 반영하기위해 다양한 제품카테고리들을 포함시켜려 하였다. 또한 기존 연구들(Sandell, 1968 ; Clark \& Belk, 1979)에서 음용 상황이 구매행동에 중요한 변수라는 점올 감안하여 카테 고리 수준에서의 지각적 경쟁 구조의 cue가 될 것이라고 예상할 수 있는 음료수 제품을 그 연구대상으로 정한 것이다. 연구에서 이용된 음료제품 카테고리와 브랜드는 다음과 같다. 특히 브랜드 수준의 브랜드들은 조사시점에서 농심가수퍼 시장점유율을 토대로 선정하였다.

\section{<표 1> 음료제품의 분류}

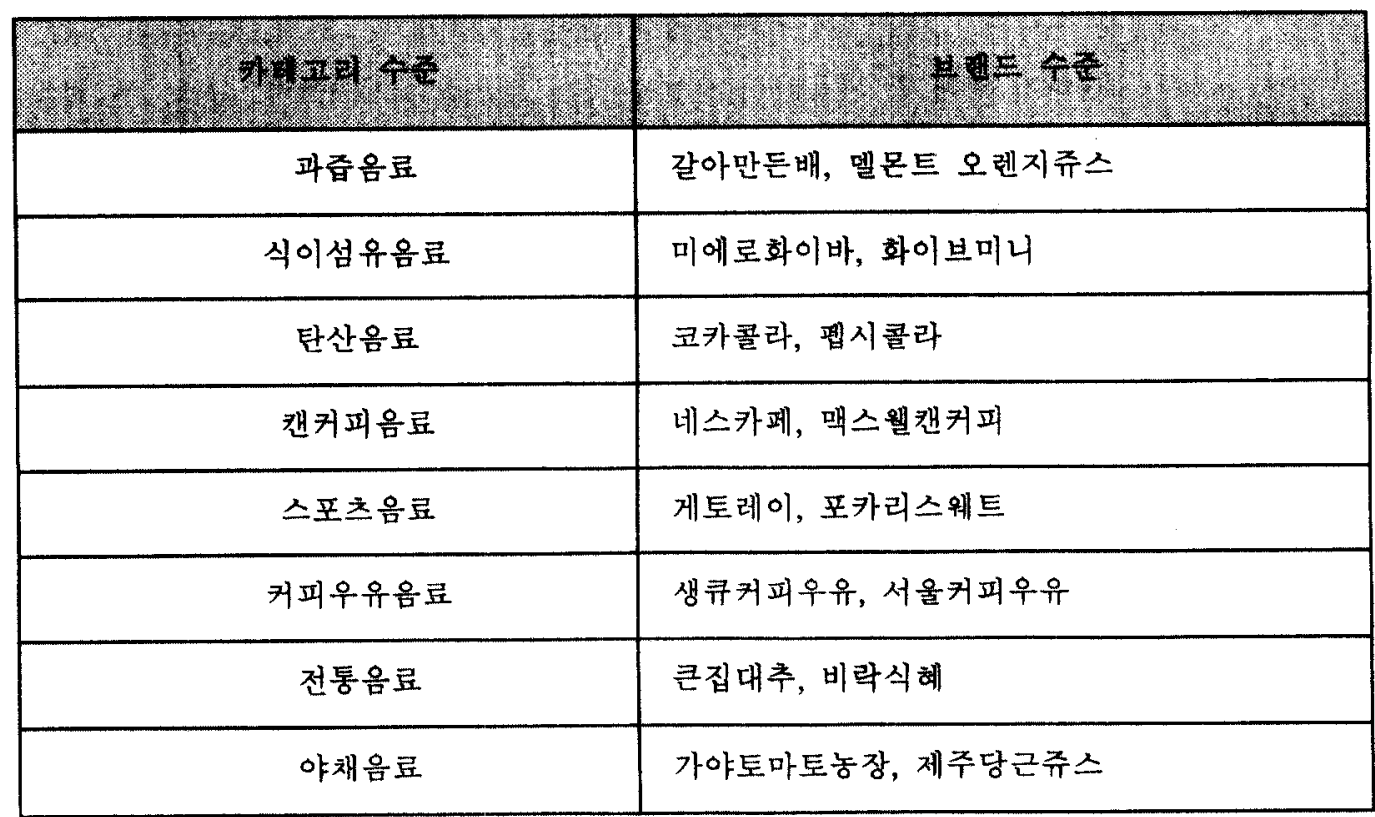




\section{2. 상황 변수의 도출}

본 연구에서는 상황의 세 가지 유형 중 '소비상황'을 상황 변수로 사용하였다. 음료수의 소비(욤용)상황 변수들의 선정을 위해서는 Bearden \& Woodside(1976)의 연구에서 제시되었던 7가지 음료수 음용 상항(집에서 놀고 있을 때, 스포츠활동에 참여할 때, 여행을 할 때, 간식 을 먹고 있을 때, 줄기는 음식과 함께, 근무 중 잠시 휴식을 취할 때, 저녁식사와 합께)과 본 연구에서 실시한 남녀 대학생 10명을 대상으로 한 표적집단면접(FGI; Focus Group Interview) 결과률 토대로 하여 <표 2>와 같이 5 가지의 음료수 음용 상황을 선정하였다.

\section{<표 2> 욤료수의 소비(윰용)상황}
口 상황 1: 운동 후 갈증 나는 상황
[1] 상황 2: 식사 후에 음료수률 마시는 상황
$\square$ 상황 3:스낵/과자 둥과 함째 마시는 상황
망항 4 : 문득 무엇인가를 마시고자 하는 상황
망황 5: 친구, 동료들과 같이 대화하면서 마시는 상황

\section{3. 설문지의 구성}

본 연구를 수행하기 위한 설문지는 다음과 같이 구성되었다. 먼저, 소비자의 지각 속 경쟁 구조률 도출하기 위해 각 제품간 유사성울 묻는 설문을 실시하였다. 이는 두 제품씩 쌍을 지은 후 각 쌍에 대하여 유사성을 7점 척도룰 이용하여 평가하도록 하였다. 또한 상 황별로 해당 제품을 '전혀 마시고 싶지 않다-매우 마시고 싶다'의 7점 척도률 이용하여 다 섯 가지 상황에서 해당제품을 얼마나 마시고 싶은지의 구매의도를 질문하였다.

\section{4. 분석방법}

\subsection{1 경쟁 구조 분석}

본 연구에서는 경쟁 구조률 분석하기 위해 군집분석을 사용하기로 한다. 군집분석은 분류기준이 불명확할 경우에 주로 이용되는 기법으로 대상에 대한 상호관계를 파악하는데 초점을 두는 기법이다. 군집분석의 방법은 크게 계충적 군집분석과 비계층적 군집분석으로 
나눌 수 있는데 본 연구예서는 일반적으로 이용되는 계충적 분석방법을 사용하기로 한다. 계층적 군집분석은 모든 대상들이 각각 하나의 독립된 군집을 이루고 있는 상태에서 출발하 여 순차적으로 가장 유사한 대상들끼리 군집화하여 감으로써 유사성이 높은 군집을 이루며, 최종적으로 모든 대상이 하나의 군집으로 몪여지는 방법이다. 본 연구에서는 계충적 군집방 법 중 평균거리결합방식을 이용하여 경쟁 구조를 분석 하기로 하며, 유사성의 평가방법은 유클리드 제곱거리를 사용하기로 한다. 유률리드 제곱거리(squred Euclidean distance)는 SAS의 평균거리결합방식을 사용할 때 지정되는 유사성 척도의 방법이다. 이 방법은 제품간의 구매 의도의 차이가 작올수록(거리가 가까울수록) 강한 경쟁관계가 성립된다. 그러나 상황 변수에 따른 음료수의 구매의도 측정척도 상 거리가 샅다면 높은 구매의도를 갖는 제품의 경쟁관계 와 낮은 구매의도를 갖는 제품의 경쟁관계가 같게 되는 문제가 있을 수 있다. 예를 들어, '식사 후 음료수를 마시려는 상황'에서 코카콜라와 네스카페의 구매의도가 7점 척도상 7점 과 6점에 해당하며 게토레이와 미에로화이바가 2점과 1점이라면, 이때 일반적인 거리를 이 용하게 되면 코카콜라와 네스카페 그리고 게토레이와 미에로화이바의 구매의도 차이, 즉 두 제품간 거리는 1 로 동일하다. 이는 코카콜라-네스카페의 경쟁정도와 게토레이-미에로화이바 의 경쟁정도가 같다는 것인데 소비자들의 구매의도률 토대로 한 경쟁관계라는 점에서 불 때 식사 후 상황에서 매우 마시고 싶은 두 제품과 마시고 싶지 않은 두 제품간의 차이는 다르 게 보는 것이 더 타당할 것이다. 따라서 구매의도가 높은 두 제품간의 경쟁강도가 더 강하 게 나타나도록 하기 위해 다옴과 같이 제품간의 거리에 가중치를 부여하였으며, 구체적인 수식은 다음과 같다. 여기서 $1 / B_{i} B_{j}$ 의 가중치는 동일한 크기의 차이라 하더라도 높은 구 매의도률 갖는 제품간의 거리가 더 가깝도록 하는, 즉 경쟁강도가 높아지도록 만들어준다.

$$
\begin{gathered}
d_{i j}=\left(B_{i}-B_{j}\right)^{2}, 1 /\left(B_{i} \cdot B_{j}\right) \\
B_{i}=\sum_{i=1}^{n} b_{i} / N, \quad\left(b_{i}=i \text { 번째 제품의 구매의도 }\right) \\
B_{i}=\sum_{j=1}^{n} b_{j} / N, \quad\left(b_{j}=j\right. \text { 번째 제품의 구매의도) }
\end{gathered}
$$

\subsection{2 경쟁 구조의 비교}

가설을 검증하기 위해서는 지각적 경쟁 구조와 상황별 경쟁 구조를 비교해야 한다. 여기 서는 한상만 ·김소영(1997)의 연구에서 사용한 경쟁 구조간의 비교 분석 방법인 서열상관분 석을 이용하기로 한다. 본 연구에서는 소비자의 지각적 경쟁 구조와 각 상황별 경쟁 구조 가 차이가 있는지를 스피어만 서열상관계수(Sperman's rank oder correlation coefficient)를 이용하 여 분석하였다. 이것은 지각적 경쟁 구조와 상황별 경쟁 구조의 척도에 차이가 있고 특히 
상황별 경쟁 구조의 경우 가중치률 부여하였기 때문에 제품간 거리 측정치의 상관관계는 의 미률 가지지 못하기 때문이다. 분석을 위한 자료는 제품둘간 유사성 행렬의 값둘을 제품간 의 거리 값이 작은 순서, 즉 경쟁의 정도가 큰 순서대로 서열척도로 변환 시킨 후 이를 이 용하여 서열상관분석을 실시하였다. 두 경쟁 구조의 행렬에 제시되어 있는 지수 값들을 거 리가 가장 가까운 것부터 가장 먼 것까지, 즉 경쟁강도가 강한 것부터 약한 순으로 자료들 을 변환시킨 후 이를 토대로 서열상관분석을 실시하여 두 경쟁 구조간 상관계수를 파악하였 다.

\section{5. 분석졀과}

\section{1. 가설 1 의 검중}

: 브랜드 수준에서의 지각적 경쟁 구조와 상황적 경쟁 구조의 비교

브랜드 수준에서 소비자들의 상표들간 지각된 유사성 측정치들을 평균하여 구해낸 <표 $3>$ 의 유사성 지각행렬을 이용하여 계충적 군집분석을 실시한 결과 <그립 $2>$ 와 같은 브랜드 수준에서의 지각적 경쟁 구조를 파악할 수 있었다. 지각적 경쟁 구조는 탄산음료, 이온음료, 커피음료 둥과 같이 물리적 속성의 유사성을 토대로 강한 경쟁관계률 갖는 하부시장을 구성 하고 있다.

<표 3> 브랜드 수준-지각적 경쟁 구조의 유사성 행렬

\begin{tabular}{|c|c|c|c|c|c|c|c|c|c|c|c|c|c|c|c|c|}
\hline 상표 & 1 & 2 & 3 & 4 & 5 & 6 & 7 & 8 & 9 & 10 & 11 & 12 & 13 & 14 & 15 & 16 \\
\hline 1 & 0 & & & & & & & & & & & & & & & \\
\hline 2 & 0.656 & 0 & & & & & & & & & & & & & & \\
\hline 3 & 4.906 & 5.062 & 0 & & & & & & & & & & & & & \\
\hline 4 & 4.500 & 4.875 & 3.250 & 0 & & & & & & & & & & & & \\
\hline 5 & 3.906 & 4,062 & 4.906 & 5.031 & 0 & & & & & & & & & & & \\
\hline 6 & 3.843 & 3.968 & 4.843 & 4.843 & 0.218 & 0 & & & & & & & & & & \\
\hline 7 & 5.312 & 5.125 & 2.625 & 2.093 & 5.187 & 5.406 & 0 & & & & & & & & & \\
\hline 8 & 5.156 & 5.281 & 2.687 & 2.125 & 5.031 & 5.312 & 1.281 & 0 & & & & & & & & \\
\hline 9 & 4.281 & 4.531 & 4.593 & 4.406 & 2.250 & 2.281 & 4.437 & 4.781 & 0 & & & & & & & \\
\hline 10 & 4.250 & 4.281 & 4.625 & 4.812 & 2.187 & 1.968 & 4.875 & 4.656 & 0.187 & 0 & & & & & & \\
\hline 11 & 3.406 & 3.843 & 4.062 & 4.375 & 4.656 & 4.625 & 4.531 & 4.843 & 5.000 & 5.093 & 0 & & & & & \\
\hline 12 & 3.562 & 3.706 & 3.781 & 4.343 & 4.593 & 4.625 & 4.531 & 4.531 & 4.718 & 4.875 & 0.593 & 0 & & & & \\
\hline 13 & 4.625 & 4.437 & 4.000 & 3.687 & 5.031 & 4.937 & 4.093 & 3.843 & 4.781 & 4.906 & 3.312 & 3.000 & 0 & & & \\
\hline 14 & 4.812 & 4.781 & 4.062 & 4.031 & 4.843 & 5.031 & 3.812 & 4.000 & 4.656 & 4.656 & 3.375 & 3.343 & 0.375 & 0 & & \\
\hline 15 & 5.093 & 4.875 & 2.562 & 3.406 & 5.187 & 5.000 & 2.125 & 2.593 & 4.812 & 4.968 & 4.843 & 4.750 & 4.343 & 4.4688 & 0 & \\
\hline 16 & 4.968 & 4.875 & 2.593 & 3.281 & 4.687 & 4.906 & 3.093 & 3.000 & 4.375 & 4.593 & 4.500 & 4.531 & 4.406 & 4.4375 & 2.031 & 0 \\
\hline
\end{tabular}

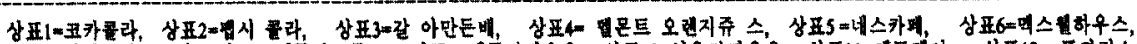

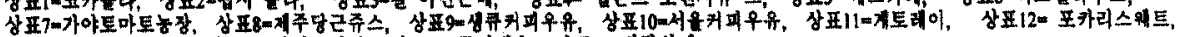

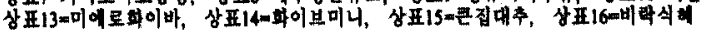




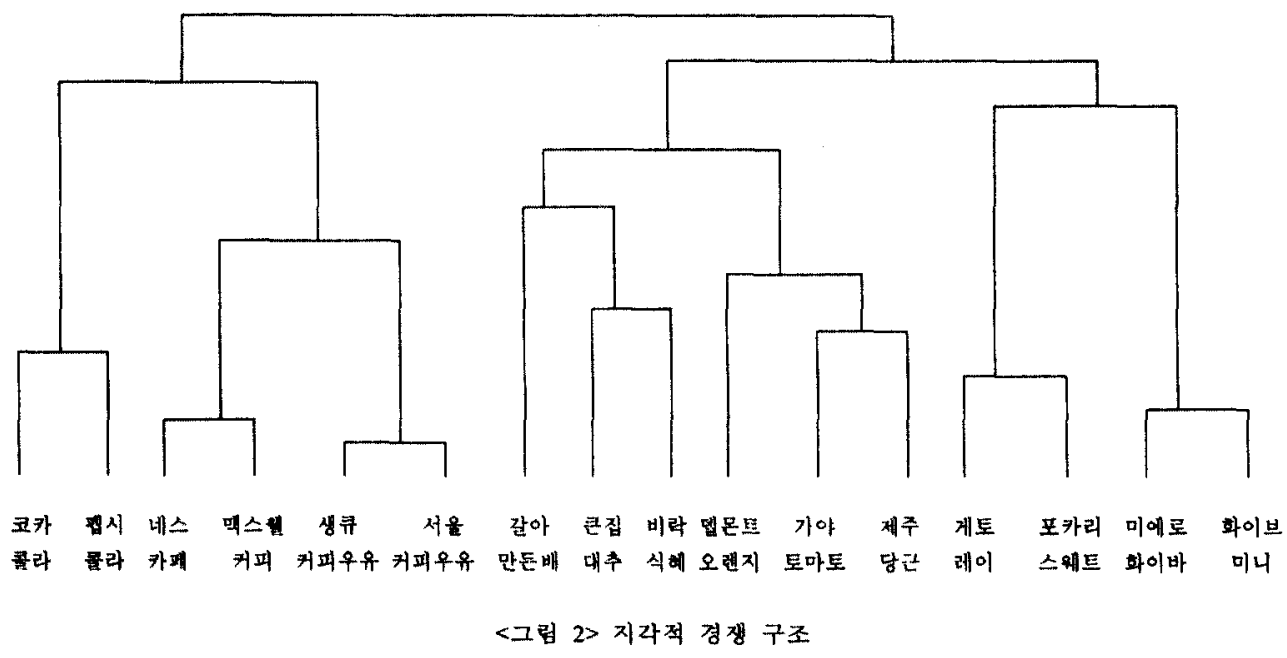

브랜드 수준에서의 상황적 경쟁 구조를 파악하기 위해서 각 상황별 소비자들의 브랜드들 에 대한 구매의도 측정치률 평균하여 구해낸 값을 식(1)의 알고리츰을 이용하여 거리로 환 산한 후 유사성 행렬을 만든 다옴, 이률 토대로 계충적 군집분석을 실시하였다. <표 4>에 는 브랜드 수준에서 ‘문득 무엇인가률 마시려는 상황'에서의 브랜드들간 지수 행렬을 제시 하고 있으며, 이를 이용하여 군집분석을 한 결과가 <그립 3>에 제시되어 있다.

<표 4> 브랜드 수준- '문득 무엇인가를 마시려는 상황' 유사성 행렬

\begin{tabular}{|c|c|c|c|c|c|c|c|c|c|c|c|c|c|c|c|c|}
\hline 상표 & 1 & 2 & 3 & 4 & 5 & 6 & 7 & 8 & 9 & 10 & 11 & 12 & 13 & 14 & 15 & 16 \\
\hline 1 & 0.0000 & & & & & & & & & & & & & & & \\
\hline 2 & 0.0027 & 0.0000 & & & & & & & & & & & & & & \\
\hline 3 & 0.0007 & 0.0007 & 0.0000 & & & & & & & & & & & & & \\
\hline 4 & 0.0148 & 0.0048 & 0.0092 & 0.0000 & & & & & & & & & & & & \\
\hline 5 & 0.0329 & 0.0166 & 0.0241 & 0.0035 & 0.0000 & & & & & & & & & & & \\
\hline 6 & 0.0387 & 0.0208 & 0.0292 & 0.0056 & 0.0002 & 0.0000 & & & & & & & & & & \\
\hline 7 & 0.2069 & 0.1611 & 0.1836 & 0.1094 & 0.0734 & 0.0652 & 0.0000 & & & & & & & & & \\
\hline 8 & 0.3885 & 0.3234 & 0.3556 & 0.2468 & 0.1900 & 0.1766 & 0.0265 & 0.0000 & & & & & & & & \\
\hline 9 & 0.0599 & 0.0369 & 0.0478 & 0.0150 & 0.0040 & 0.0023 & 0.0430 & 0.1381 & 0.0000 & & & & & & & \\
\hline 10 & 0.0727 & 0.0470 & 0.0593 & 0.0216 & 0.0077 & 0.0052 & 0.0333 & 0.1201 & 0.0006 & 0.0000 & & & & & & \\
\hline 11 & 0.1152 & 0.0820 & 0.0981 & 0.0468 & 0.0246 & 0.0200 & 0.0129 & 0.0766 & 0.0088 & 0.0048 & 0.0000 & & & & & \\
\hline 12 & 0.1091 & 0.0770 & 0.0925 & 0.0430 & 0.0219 & 0.0176 & 0.0150 & 0.0816 & 0.0072 & 0.0036 & 0.0001 & 0.0000 & & & & \\
\hline 13 & 0.1091 & 0.0770 & 0.0925 & 0.0430 & 0.0219 & 0.0176 & 0.0150 & 0.0816 & 0.0072 & 0.0036 & 0.0001 & 0.0000 & 0.0000 & & & \\
\hline 14 & 0.1640 & 0.1237 & 0.1434 & 0.0792 & 0.0491 & 0.0425 & 0,0024 & 0.0448 & 0.0251 & 0.0179 & 0.0042 & 0.0054 & 0.0054 & 0.0000 & & \\
\hline 15 & 0.3734 & 0.3097 & 0.3412 & 0.2350 & 0.1797 & 0.1667 & 0.0228 & 0.0001 & 0.1294 & 0.1120 & 0.0702 & 0.0750 & 0.0750 & 0.0400 & 0.0000 & \\
\hline 16 & 0.0186 & 0.0071 & 0.0122 & 0.0002 & 0.0020 & 0.0036 & 0.0999 & 0.2322 & 0.0116 & 0.0176 & 0.0407 & 0.0372 & 0.0372 & 0.0712 & 0.2208 & 0.000 \\
\hline
\end{tabular}

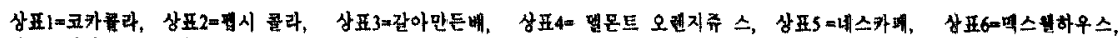

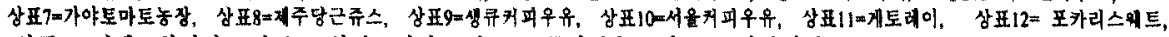

상표13=미에로화이바, 상표14m화이브미느, 상표15=흔집대추, 상표16m비락식해 


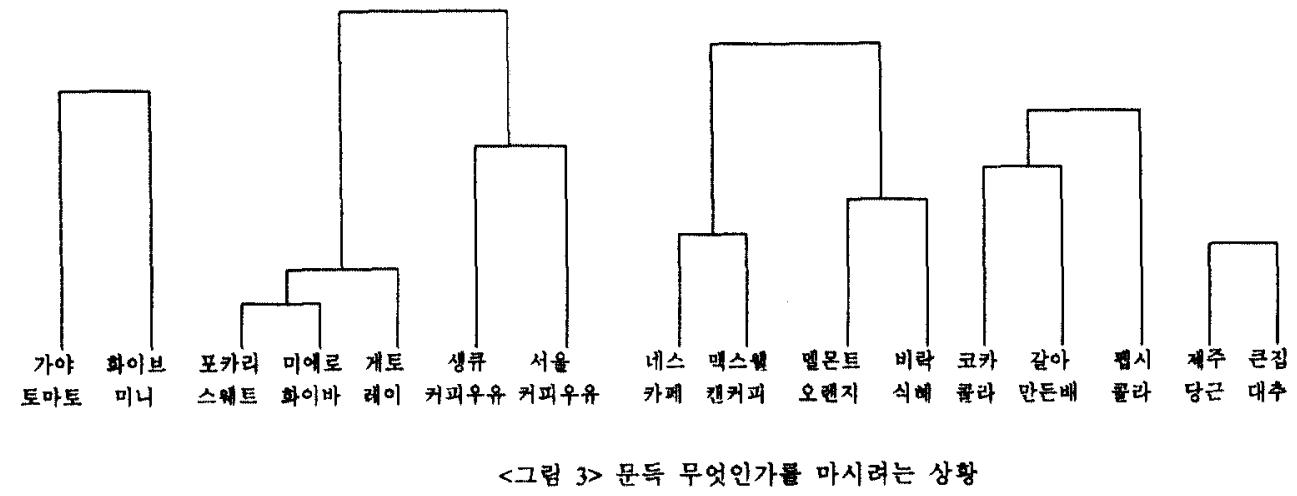

<표 3>은 두 브랜드간 유사성 거리률 나타내는 것으로 그 값이 작은 것온 가장 유사성 거리가 가까운 것으로 이는 두 제품간 경쟁강도가 가장 강한 것을 의미하며, 반대로 값이 가장 큰 것은 가장 유사하지 않은 것으로 두 제품간 경쟁강도가 가장 약한 것을 의미한다. <표4>도 두 브랜드간 거리가 가까울수록 경쟁강도가 강한 것을 의미한다. 동일한 방법으로 나머지 상황들에 대해서도 시장의 경쟁구조률 파악하였다.

브랜드 수준에서 지각적 경쟁 구조와 상황적 경쟁 구조를 비교하기 위해서는 우선 각 경 쟁 구조의 지수 행렬에 제시되어 있는 값들을 경쟁정도의 순서대로 서열척도로 변환시킨 후 이률 이용하여 스피어만 서열상관분석(Spearman's rank order correlation analysis)을 실시하였다. 예률 들어, <표3>의 지각적 경쟁 구조의 행렬과 <표4>의 상황적 경쟁 구조의 행렬에 제시되 어 있는 값들을 거리가 가장 가까운 것부터 가장 먼 것까지, 즉 경쟁강도가 강한 것부터 약 한 것으로 순서대로 지수 값듈을 서열척도로 변환시킨 후 이 자료률 토대로 서열상관분석을 실시하여 두 경쟁 구조간 서열상관계수률 퐈악하였다(한상만 김소영, 199 7).

이렿게 해서 구한 지각적 경쟁 구조와 5 가지 상항별 경쟁 구조률 비교한 스피어만 서열 상관계수는 <표 $5>$ 와 같다.

<표 5> 브랜드 수준 지각적 경쟁 구조와 상황적 경쟁 구조 스피어만 서열상관계수 $(\rho)$

\begin{tabular}{|c|c|c|c|c|c|}
\hline & (fin) & 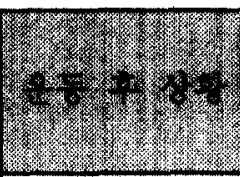 & 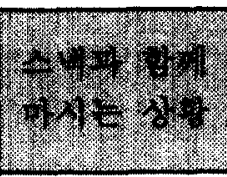 & P & 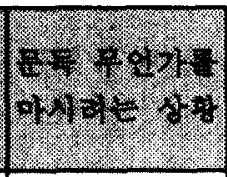 \\
\hline 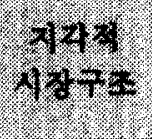 & -0.02 & 0.14 & 0.2 & 0.19 & 0.16 \\
\hline
\end{tabular}


일반적으로 상관계수의 절대값이 0.2 이하이면 상관관계가 없거나 무시해도 줗은 수준이 며, 0.4정도면 약한 상관관계, 0.6 이상이면 강한 상관관계로 볼 수 있다(채서일 1995). <표 $5>$ 를 보면 브랜드 수준에서 지각적 경쟁 구조와 각 상황별 경쟁 구조를 비교 분석한 결과 서열 상관 계수 값이 모두 0.2 이하로 브랜드 수준에서 지각적 경쟁 구조와 상황적 경쟁 구 조는 상이하다는 사실을 알 수 있다. 따라서 브랜드 수준에서 지각적 경쟁 구조와 상황적 경쟁 구조를 비교 분 석한 결과 가설 1 은 지지되었다.

\section{2. 가설 2 의 검증}

: 카테고리 수준에서의 지각적 경쟁 구조와 상황적 경쟁 구조의 비교

카테고리 수준에서의 지각적 경쟁 구조와 상황적 경쟁 구조는 앞의 브랜드 수준에서와 동 일한 과정으로 분석되었다. 우선, 카테고리 수준에서의 지각적 경쟁 구조의 유사성 행렬 < 표 6>을 토대로 <그럼 4>에서는 카테고리 수준에서의 지각적 경쟁 구조를 제시하고 있다. 카테고리 수준에서의 지각적 경쟁 구조를 살펴보면, 탄산음료와 과즙옴료 그리고 이온음료 가 하나의 하부시장을 형성하고 있고, 야채음료와 섬유음료 및 커피음료가 하부시장을 형성 하고 있으며, 전퉁음료와 커피우유가 하나의 하부시장올 형성하면서 경쟁관계를 나타내고 있음을 알 수 있다.

카테고리 수준에서의 상황적 경쟁 구조 분석도 브랜드 수준에서와 마찬가지로 각 상황별 소비자들의 카테고리들에 대한 구매의도 측정치를 평균하여 구해낸 값을 식(1)의 알고리즘 을 이용하여 거리로 환산한 후 지수 행렬을 만든 다음, 이를 토대로 계충적 군집분석을 실 시하였다. <표 7>에서는 카테고리 수준에서 '식사 후 마시는 상황' 에서의 카테고리들간 거리률 제시하고 있으며, 이를 이용하여 군집분석을 한 결과가 <그림 $5>$ 에 제시되어 있다.

<표 6> 카테고리 수준 - 지각적 경쟁 구조의 유사성행렬

\begin{tabular}{|c|c|c|c|c|c|c|c|c|}
\hline 카테고리 & 1 & 2 & 3 & 4 & 5 & 6 & 7 & 8 \\
\hline 1 & 0.0000 & & & & & & & \\
\hline 2 & 0.2000 & 0.0000 & & & & & & \\
\hline 3 & 0.8571 & 1.9857 & 0.0000 & & & & & \\
\hline 4 & 2.1286 & 2.6571 & 1.2571 & 0.0000 & & & & \\
\hline 5 & 4.8143 & 4.5714 & 2.1429 & 1.0857 & 0.0000 & & & \\
\hline 6 & 3.9571 & 3.6429 & 1.0000 & 0.5000 & 0.9571 & 0.0000 & & \\
\hline 7 & 1.6000 & 2.7714 & 1.7143 & 0.1429 & 1.3714 & 2.8000 & 0.0000 & \\
\hline 8 & 1.1143 & 1.3143 & 2.1000 & 3.9000 & 3.9286 & 2.1143 & 1.7714 & 0.0000 \\
\hline & $\begin{array}{l}\text { 욤료, } \\
\text { 음료, }\end{array}$ & $\begin{array}{l}2=\text { 과줍음 } \\
6=\text { 커피우 }\end{array}$ & & $\begin{array}{l}\text { 거퍼음표, } \\
\text { 범유음표, }\end{array}$ & $\begin{array}{l}4=0 \text { 얒 } \\
8=0 \text { 이 }\end{array}$ & & & \\
\hline
\end{tabular}


<표 7> 카테고리 수준 - ‘식사 후 상황' 지수 행렬

\begin{tabular}{|c|c|c|c|c|c|c|c|c|}
\hline 카테고리 & 1 & 2 & 3 & 4 & 5 & 6 & 7 & 8 \\
\hline 1 & 0.0000 & & & & & & & \\
\hline 2 & 0.0025 & 0.0000 & & & & & & \\
\hline 3 & 0.0478 & 0.0283 & 0.0000 & & & & & \\
\hline 4 & 0.2644 & 0.2138 & 0.0849 & 0.0000 & & & & \\
\hline 5 & 0.5302 & 0.4555 & 0.2498 & 0.0419 & 0.0000 & & & \\
\hline 6 & 0.3704 & 0.3095 & 0.1472 & 0.0083 & 0.0129 & 0.0000 & & \\
\hline 7 & 0.0846 & 0.0577 & 0.0051 & 0.0481 & 0.1817 & 0.0967 & 0.0000 & \\
\hline 8 & 0.0305 & 0.0155 & 0.0019 & 0.1127 & 0.2970 & 0.1835 & 0.0133 & 0.0000 \\
\hline & $\begin{array}{l}\text { 음료, } \\
\text { 음료, }\end{array}$ & $\begin{array}{l}2=\text { 과즘 } \\
6=\text { 커피 }\end{array}$ & & 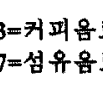 & $\begin{array}{l}4= \\
8=\end{array}$ & 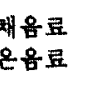 & & \\
\hline
\end{tabular}
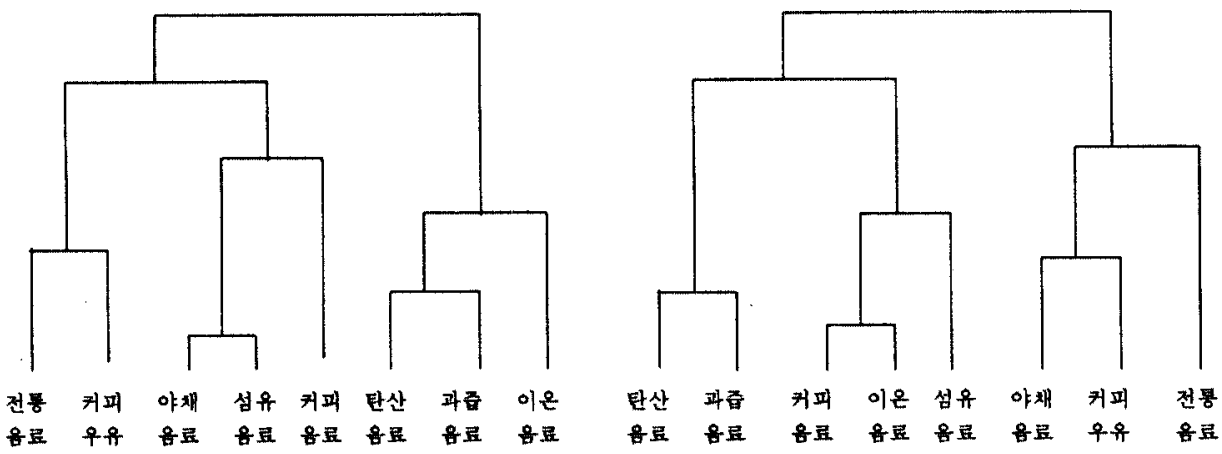

<그림 4> 지각적 경쟁 구조

<그림 5> 식사 후 마시는 상황

카테고리 수준에서 지각적 경쟁 구조와 상황적 경쟁 구조률 비교 분석한 결과를 통해 가설 2 률 검중하기로 한다. 브랜드 수준에서와 마찬가지로 두 경쟁 구조의 비교를 위해 스 피어만 서열상관계수(Spearman's rank order correlation coefficient)를 이용하였다.

<표 8> 카테고리 수준 지각적 경쟁구조와 상황적 경쟁구조 스피어만 서열상관계수 $(\rho)$

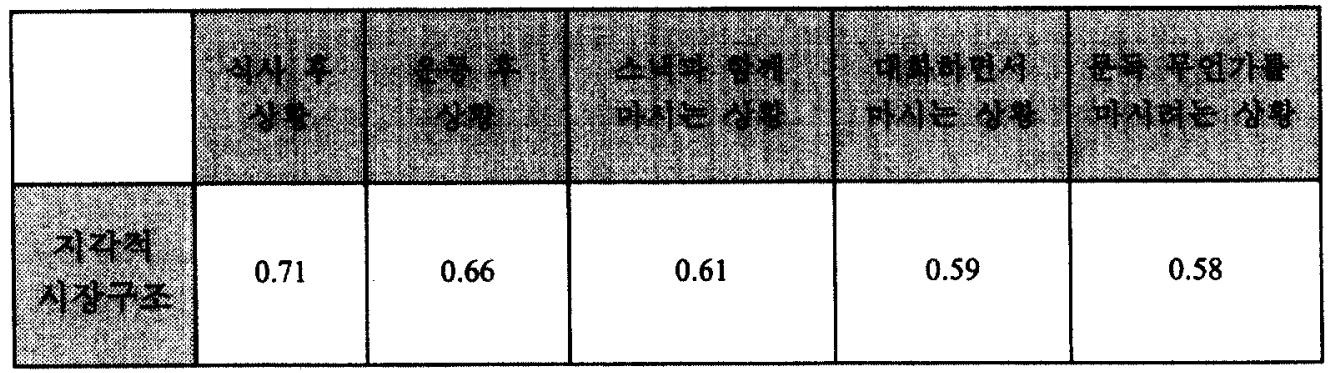

앞서 논의했던 브랜드 수준에서의 졀과와는 달리 지각적 경쟁 구조와 상황 별 경쟁 구조 
는 모든 경우에 상관계수가 $0.6 \sim 0.7$ 로서 상관계수가 0.6 이상이면 강한 상관관계로 불 수 있 다(채서일 1995). 이률 뚱해 카테고리 수준에서의 지각적 경쟁 구조와 상황적 경쟁 구조간 에는 높은 상관관계가 있다는 사실을 확인할 수 있었으며, 따라서 지각적 경쟁 구조와 각 상황별 경쟁 구조는 유사할 것이라는 가설 2 는 지지되었다. 음료수제품에 있어 옴용 상황 이라는 기준이 소비자들의 구매선택에 강력한 예측도구로서 매우 중요한 영향을 미친다는 연구 결과들을 토대로, 본 연구에서는 소비자둘은 음료수와 관련하여 장기 기역 속에 음용 상황이라는 기준(cue)을 토대로 스키마를 형성하고 있율 것이라고 예상하였으며, 이에 음용 상황이라는 기준을 제시한 상태에서 카테고리 수준에서의 음용 상황별 경쟁 구조를 파악하 였다. 그리고 카테고리 수준에서의 지각적 경쟁 구조는 브랜드 수준에서 와는 달리 제품들 간의 물리적 속성이라는 기준을 사용하기 어럽기 때문에 소비자의 인지적 노력을 가장 덜 들이는 가장 친숙한 기준을 이용하여 장기 기억 속에 있는 옴료수관련 스키마를 토대로 제 품들의 유사성평가라는 범주화 과업을 수행 할텐데 바로 이때 사용되는 기준이 음용 상황이 라면 지각적 경쟁 구조와 음용 상황적 경쟁 구조는 유사할 것이라고 보았다. 결국 가설 2 가 지지됨으로써 음료수와 관련한 소비자들의 머리 속에는 음용 상황이라는 기준을 토대로 한 스키마가 형성되어 있다고 볼 수 있다.

그런데 본 연구에서는 기존 연구들을 토대로 가장 높은 가능성이 있는 기준을 미리 정해 놓고 카테고리 수준에서의 지각적 경쟁 구조와 음용 상황별 경쟁 구조를 비교하여 그 일치 여부를 토대로 소비자의 장기 기억 속의 음료수관련 범주화 기준과 스키마에 관한 정보를 얻어낼 수 있었다. 그러나 사실상 음료수이외의 다른 제품군에서는 어떠한 구체적인 상황 변수가 범주화의 기준으로 작용하게 될 지는 알 수 없다. 또한 소비상황, 구매상황 및 커뮤 니케이션 상황으로 구성되는 상황 변수이외의 다른 변수가 범주화 과업을 수행하는데 기준 으로 사용될 수도 있을 것이다. 결국 여러 가지 가능한 기준들을 제시하고 각 기준마다 경쟁 구조를 파악한 후 카태고리 수준에서의 지각적 경쟁 구조와 일치하는 경쟁 구조를 찾 아 해당제품군별 어떤 범주화 기준이 사용되었는지를 파악해야 할 것이다. 여기서 본 연구 는 이러한 일련의 과정을 간단히 할 수 있도록 다음과 같은 분석과정율 제시하고자 한다. 우선, 카테고리 수준에서의 지각석 경쟁 구조를 파악함에 있어 프로토골(protocol)을 이용하 는 것이다. 프로토콜은 소비자행둥의 서술적 모델(descriptive model)을 파악하는 것으로 개 인 소비자들은 선택집합(choice set)에 속한 여러 상표들 중에서 어느 한 상표를 선택하기 위 해 그와 관련되는 여러 정보들을 확득하고, 조직화하고, 이용함에 있어 일련의 계충적 정보 처리과정을 거친다고 기술하고 있는 정보처리이론을 전제로 하고 있는 것이며 이러한 프로 토콜자료를 이용하여 소비자의 선택 과정 구조에 대한 유용한 정보를 흭득할 수 있 다.(Bettman 1970, 1971) 따라서 프로토콜을 이용하여 카테고리 수준에서의 제품들간 유사성 을 평가하는 과업을 수행해나가는 과정에서 과업수행과 관련하여 머리 속에 떠오르는 것과 
생각나는 모든 것을 있는 그대로 소리 내어 말하도폭(think aloud) 하는 언어 프로토콜(verbal protocol)을 실시한 후 충 피헙자들에서 나온 기준들을 세분화할 수 있게 된다. 즉 몇 개의 가능한 기준(cue)으로 요약할 수 있고 이렇게 얻어진 정보를 토대로 각 기준별 경쟁 구조를 분석하도록 하는 것이다. 예률 들어 옴용 상황이라는 기준이 나왔다면 음용 상황별 경쟁 구조률 분석하는 것이다. 이렇게 몇 개의 기준마다 경쟁 구조를 파악한 다음 각각의 경쟁 구조 분석졀과와 카테고리 수준에서의 지각적 경쟁 구조가 일치하는 것이 어떤 것인지를 파 악하여 일치하는 기준에 의한 경쟁 구조가 바로 소비자들이 해당제품군과 관련하여 구매경 헙 둥율 토대로 장기 기역 속에 잘 확립되어 있는 인지적 구조, 즉 스키마라고 말할 수 있 는 것이다.

이상에서 가설1과 가설 2 의 검중결과 모든 가설이 지지되었음을 알 수 있다. 가설1의 검 중결과 우리는 경쟁 구조 분석에 있어 지각적 경쟁 구조와 상황적 경쟁 구조의 차이률 퉁해 보다 소비자 중심적인 경쟁 구조의 파악을 위해서는 상황적 경쟁 구조 분석이 필요하다는 사실을 제시할 수 있다. 또한 상황 변수률 토대로 한 경쟁 구조 분석을 실시함에 있어 어 떠한 구체적 상황 변수률 토대로 해야 하는가에 대한 해답을 제공하기 위해 기존연구결과 이미 중요한 상황 변수로 음용 상황 변수가 제시되어 있는 음료수제품을 대상으로 음용 상 황별 경쟁 구조와 카테고리 수준에서 지각적 경쟁 구조를 비교한 결과 두 경쟁 구조가 상당 히 일치하고 있음을 파악할 수 있었으며 이는 소비자들이 음용 상황이라는 기준을 이용하여 장기 기억 속의 스키마를 토대로 음료수경쟁 구조률 형성하고 있다는 사실을 알 수 있게 해 준다. 여기서 소비자둘은 음료수시장에 관해 머리 속에 음용 상황이라는 기준을 토대로 한 스키마 즉, 기역 속의 경쟁 구조률 형성하고 있으며, 이는 상당히 안정적인 경쟁 구조로서 지각적 단계에서의 물리적 속성이라는 기준에 의한 경쟁 구조나 선택단계에서의 판촉, 선택 집합(choice set), 다양성추구 등과 같은 외생변수에 의해 단기적이며 왜곡둴 여지가 있는 경 쟁 구조 분석보다 더욱 더 안정적이며 해당제품시장에서 가장 중요한 상황 변수률 토대로 한 장기 기억 속의 스키마에 관한 정보를 제공해주는 유용한 경쟁 구조 분석이라고 볼 수 있다.

이는 소비자들이 브랜드 수준에서 제품듈간 유사성 평가률 통해 제품들에 대한 범주화률 실시함에 있어 제품들간 물리적 속성의 유사성이라는 기준을 토대로 하였다는 사실을 제시 하는 것이며 반면 물리적 속성으로는 범주화가 어려운 카테고리 수준에서는 소비자들에게 가장 친숙하면서도 인지적 노력을 덜 들이는 범주화 기준으로 음용상황을 토대로 하였다는 사실을 제시하는 것이다. 이러한 사실은 브랜드 수준에서의 지각적 경쟁 구조 분석과 카테 고리 수준에서의 지각적 경쟁 구조 분석을 비교해봄으로써 알 수 있다. 브랜드 수준의 지 각적 경쟁 구조인 <그림 2>에서 콜라음료 그리고 커피음료와 커피우유음료가 하나의 하부 
시장을 이루면서 강한 경쟁관계률 나타내는 것과는 달리 카테고리 수준의 지각적 경쟁 구조 인 <그림 $4>$ 에서는 탄산음료, 과즙음료 및 이온음료가 보다 강한 경쟁관계률 갖는 하부시장 을 구성하고 있다. 따라서 브랜드 수준의 지각적 경쟁 구조와 카테고리 수준의 지각적 경 쟁 구조는 상이하다고 추정할 수 있다. 측, 브랜드 수준에서 사용되는 범주화 기준과 카테 고리 수준에서 사용되는 범주화 기준이 상이하다는 것으로 해석할 수 있으며, 이를 통해 우 리는 카테고리 수준에서의 지각적 경쟁 구조 분석을 통해 소비자들의 머리 속에 확립되어 있는 음료수시장 스키마률 파악할 수 있는 것이다. 


\section{6. 졀른 및 연구의 한계점}

본 연구에서는 소비자 중심적인 경쟁 구조률 분석하고자 하였으며, 톡히 소비자는 그 제 품에서 얻을 수 있는 편익을 구입하는 것이라는 점에서 소비자가 제품소비에서 추구하는 편 익은 언제나 일정한 것이 아니라 그 제품을 사용하는 상황에 따라 달라진다는 점을 고려하 여 상황적 경쟁 구조 분석의 필요성을 제기하였다. 또한 대부분의 경쟁 구조 분석이 브랜 드 수준에서 이루어지고 있지만 제품의 혁신성이 높을 경우 카테고리 수준에서의 경쟁 구조 분석이 펄요하다는 주장과 함께 카테고리 수준에서의 경쟁 구조 분석방법을 제시하고 이의 유용성에 대해서도 논의하고 있다. 이처럼 카테고리 수준에서 경쟁 구조를 분석하는 것은 소비자들의 머리 속에 이미 형성되어 있는 제품구매와 관련한 장기 기억 속의 스키마가 표 출된 것으로서, 이렿게 형성된 카테고리 수준에서의 지각적 경쟁 구조 분석은 해당제품의 구매와 관련하여 소비자들에게 가장 친숙한 기준(cue)의 파악과 이 기준을 토대로 한 경쟁 구조의 파악이 가능하도록 하는 이점이 있다. 이상의 논의를 위해 본 연구에서는 두 가지 가설을 설정하였다.

첫 번째 가설은 브랜드 수준에서 지각적 경쟁 구조와 상황적 경쟁 구조는 상이할 것이라 는 것이다. 이 가설의 검중을 퉁해 상황적 경쟁 구조가 펄요하다는 주장을 제기하고자 하였 으며, 두 번째 가설은 카테고리 수준에서 지각적 경쟁 구조와 상황적 경쟁 구조가 유사할 것이라는 것이다. 여기서는 브랜드 수준에서의 경쟁 구조 분석율 통해 상황적 경쟁 구조의 필요성은 제기되었으나 여러 가지 상황 변수들 중에서도 구체적으로 어떤 상황 변수가 소비 자들의 장기 기억 속의 음료수제품 스키마를 형성하고있는 cue로 사용되었는지를 분석하기 위해 카테고리 수준에서의 지각적 경쟁 구조와 기존 연구결과 옴료수에서 가장 중요한 변수 인 소비상황 즉, 옴용 상황을 기준으로 한 경쟁 구조를 비교 분석하였다.

분석결과 두 가설은 모두 지지되었다. 따라서 경쟁 구조 분석에 있어 상황적 경쟁 구조 분석의 펼요성을 제기할 수 있었으며, 카테고리 수준에서의 지각적 경쟁 구조의 분석과 음 용 상황적 경쟁 구조 분석결과 두 경쟁 구조가 유사하다는 사실을 통해 소비자들은 음료수 구매와 관련하여 '소비(음용)상황'이라는 기준에 의해 음료수 제품들을 범주화하는, 즉 소비 자들의 머리 속에 음용 상황이라는 기준에 의한 스키마가 형성되어 있다고 볼 수 있는 근거 를 제시해주었다. 또한 이상의 졀과를 통해 본 연구에서는 다른 제품군들에 대해서도 카테 고리 수준에서의 경쟁 구조의 분석이 소비자의 장기 기억 속에 제품의 구매경험올 퉇해 어 떤 기준 즉, 범주화 기준이 중요한지에 대한 정보률 얻을 수 있게 한다는 점을 주장하고 있 다. 본 논문에서는 이미 음료수에서는 가장 높은 범주화 기준의 가능성이 있는 음용 상황 을 미리 선정하여 카테고리 수준에서의 지각적 경쟁 구조와 음용 상황별 경쟁 구조를 비교 
분석함으로써 두 경쟁 구조간 매우 높은 유사성을 통해 소비자들온 옴용 상황이라는 범주화 기준을 토대로 장기 기억 속에 옴료수시장 스키마률 학립하고 있음을 알 수 있었다. 그러 나 음료수이외의 다른 제품군들에 있어서는 어떤 범주화 기준이 사용되는지률 알 수 없기에 본 연구에서는 앞에서 언급한 것처럼 프로토콜에 의한 카테고리 수준에서의 지각적 경쟁 구 조의 분석을 제기하고 있다. 즉, 카테고리 수준에서의 제품들간 유사성평가를 하는 과정을 프로토콜올 사용함으로써 소비자들에게 범주화 과업의 기준이 된 몇 개의 기준들을 선정해 내고 이렇게 해서 선정된 각각의 cue를 기준으로 하는 경쟁 구조를 분석하여(본 연구에서의 음용 상황별 경쟁 구조 분석과 마찬가지로) 카테고리 수준의 지각적 경쟁 구조와 가장 유사 한 경쟁 구조를 제시하는 cue를 해당제품군의 장기 기억 속의 스키마를 형성하고 있는 범주 화 기준으로 보는 것이다. 이처럼 카테고리 수준에서의 경챙 구조 분석은 소비자의 장기 기억 속에 제품의 구매경헙을 통해 어떤 기준 즉, 범주화 기준이 중요한지에 대한 정보률 제공해준다는 이점이 있다.

본 논문의 마케텅 관리적 시사점은 다음과 같다.

첫째, 카테고리 수준에서의 지각적 경쟁 구조 분석은 소비자들의 장기 기억 속에 확립되 어 있는 스키마에 관한 정보를 제공할 수 있고, 이를 퉁해 소비자들의 구매와 관련하여 중 요한 변수, 가장 친숙한 범주화 기준은 무엇이며 그리고 그 기준(cue)에 의한 머리 속 인지 적 경쟁 구조는 어떻게 형성되어 있는지률 파악하는데 매우 유용한 정보률 제공해준다.

둘째, 2 단계 경쟁 구조 분석의 필요성을 제기할 수 있다. 우선, 1 단계에서는 카테고리 수 준에서 지각적 경쟁 구조를 파악한 후 경쟁관계가 강한 카테고리들만을 대상으로 2 단계에 서는 브랜드 수준에서 경쟁 구조를 파악하는 것이다. 예를 들어, 본 논문의 카테고리 수준 에서의 경쟁 구조 분석 결과 콜라음료, 과즙음료 및 이온음료가 경쟁관계에 있다는 것을 파 악할 수 있었다. 그렇다면 해당 카테고리의 마케터는 2차적으로 브랬드 수준에서 보다 구 체적인 경쟁 구조의 파악을 함에 있어 세 개의 제품카테고리이외의 경쟁관계 없는 카태고리 (식이섬유음료나 커피음료 둥)의 브랜드들올 포함시킬 필요 없이 탄산, 과줍, 이온음료에 속 하는 다양한 브랜드들만을 대상으로 브랜드 수준에서의 경쟁 구조를 파악하라는 것이다. 브랜드 수준에서 지각적 경쟁 구조를 분석하게 되면 물리적 유사성을 기준으로 제품 중심적 인 경쟁 구조가 파악되게 된다. 따라서 우선 카테고리 수준에서 소비자들이 머리 속에 안 정적으로 형성하고 있는 해당제품군의 경쟁 구조를 가악한 다음 여기에서 강한 경쟁관계를 나타내는 카테고리들만을 갖고 다음단계에서는 브랜드 수준의 지각적 경쟁 구조를 파악한다 면 단순한 물리적 속성의 기준만이 아닌 보다 소비자 중심적인 경쟁 구조 분석이 가능하리 라 본다. 이러한 2 단계 경쟁 구조 분석은 보다 구체적이고 정학한 경쟁자의 파악이라는 측 면에서 광고전략에도 유용한 시사점을 제공해준다. 
셋째, 신제품의 도입을 위한 마케팅전략과 기존제품의 방어전략에서도 활용될 수 있다.

음료시장에서 전퉁음료라고 말할 수 있는 제품이 거의 없던 상황에서 비락식혜와 같이 혁 신적인 신제품을 출시하는 기업에서는 식혜가 전통차(설록차, 인삼차 둥)와 경쟁하는지 아니 면 과즙음료나 이은음료와 같은 옴료수 제품군과 경쟁하는지를 알기 위해서는 카테고리 수 준에서의 경쟁 구조파악이 펄요하다. 만약 기존의 음료수시장의 마케터들이 식혜는 전통음 료니까 전통차나 몇몇 건강음료에만 적은 영향을 미치고 탄산음료나 이온음료와 같은 일반 적인 음료수제품군에는 거의 영향을 미치지않을 것으로 예상하고 이에 대한 대응전략올 수 립하지 않았다면 많은 어려움에 직면했을 것이다(유필화 김홍섭, 1996). 이처럽 특히 경쟁 사의 혁신적인 신제품 츨시에 대한 방어전략의 수립 시에도 카테고리 수준에서의 경쟁 구조 파악을 퉁해 신제품이 어떤 제품 카테고리에 많온 영향을 미치는지률 사전에 분석함으로써 자사제품의 효과적인 대옹전략을 수립할 수 있을 것이다.

본 연구의 한계점과 미래 연구방향은 다음과 같다.

첫째, 본 논문에서는 연구대상제품을 음료수시장에 한정하고 있다. 연구결과를 보다 일 반화시키기 위해서는 향후 다른 산업에 대해서도 브랜드 수준과 카테고리 수준에서의 상황 별 경쟁 구조 분석이 필요하다. 커피시장, 의류시장, 자동차시장 및 금융시장둥에서도 소비 자 중심적인 상황적 경쟁 구조의 분석이 펼요하며, 특히 카테고리 수준에서의 지각적 경쟁 구조와 상황 변수별 경쟁 구조의 비교를 통해 각 시장별 소비자들의 장기 기억 속에 확립되 어 있는 스키마를 토대로 소비자들이 중요시 여기는 구체적인 상황 변수에 대한 정보와 함 께 보다 안정적인 경쟁 구조의 파악이 가능하리라 본다. 특히 본 연구의 대상인 음료수 제 품은 표본집단에 매우 친숙한 제품군이다. 소비자들의 제품 친숙도의 높고 낮음에 따라 어 떠한 연구결과가 제시될 지에 대한 향후 연구도 의미있는 연구 과제라고 본다.

둘째, 본 논문에서는 연구 대상인 음료수 시장 이외의 다른 시장에서의 범주화 기준을 파 악하기 위한 하나의 가능한 대안으로 카테고리 수준에서 제품들간 유사성을 평가하는 과업 을 수행하는 과정에서 프로토쿨을 이용할 것을 제안하고 있는데 이률 실제로 실시하지 못하 였다는 한계점을 갖고 있다. 따라서 향후에는 다른 제품시장에서의 범주화 기준의 파악을 위해 본 연구에서 제시한 것처럽 프로토콜분석을 실시하여 여러 가지 가능한 상황 변수들 중 중요한 몇 개의 톡정 상황 변수를 추출해내고 이를 토대로 경쟁 구조 분석을 실시함으로 써 소비자들의 해당제품에 관한 장기 기억 속 스키마에 대한 정보와 함께 안정적인 경쟁 구 조률 파악할 필요가 있다고 본다. 


\section{참고문현}

박세훈(1995), “소비자 지향적 제품구조분석”, 마아케팅연구, 10권 2호, p103-122.

유필화 ·김훙섭(1996), 경쟁사를 미치게하는 히트겅영전략, 한 ·언

이학식 ·안광호 ·하 영 원(1999), 소비자행동, 제 2판, 법문사

채서일(1995), 마케팅조사론, 학현사

하영원 ·박홍수(1992), “광고전략수립을 위한 시장의 경쟁 구조 파악”, 광고연구, 봄호, p5-21. 한상만 ·김소영(1997), "판단적 경쟁 구조 분석과 행동적 경쟁 구조 분석의 비교연구 : 고려 상표군을 중심으로", 마케텅연구, 제12권, 제2호, 한국마케팅학회.p67-93.

Alba, Joseph W. and Hutchinson, J. W(1987), "A Framework for Understanding Consumer knowledge: II. Comparison and Inference Precesses," working paper, Center for Consumer Research, University of Florida, Gainesville, FL 32611.

Bearden, W. O., and Woodside, A. G. (1976), "Interactions of Consumption Situations and Brand Attitudes," Journal of Applied Psychology, 61, pp. 764-769.

Bearden, W. O., and Woodside, A. G. (1978), "Consumption Occasion Influence on Consumer Brand Choice," Decision Science 9, April, pp. 273-284.

Bettman, J. R.(1970), "Information Processing models of Consumer Behavior" Journal of Marketing Research, Vol.VII(Aug.), pp. 370-376

Bettman, J. R.(1971), "The Structure of Consumer Choice Processes", Journal of Marketing Research, Vol. VIII(Nov.), pp.465-471

Brucks, Merrie (1986), "A Typology of Consumer Knowldege Content," in Advances in Consumer Research, Vol. 13, p58-63

Clarke, Keith, and Belk, R. W.(1979), "The Effects of Product Involvement and Task Definition on Anticipated Consumer Effort,' Advances in Consumer Research, Vol. 6 p313-318.

Czepiel John A.(1992), “Competitive Marketing Strategy," Prentice Hall, Inc., N.J.

Day, G. S., Shocker, A. D, and Srivastava, R. K (1979), "Customer-oriented Approaches to Identifying Product-Markets," Journal of Marketing 43, Fall, p8-19.

Engel, J. F., Blackwell, R. D., and Miniard, P. W.(1995), Consumer Behavior, 8th ed. The Dryden Press. Marlatt, A. G.(1995), Addictive Behavior : Cue Exposure Theory and Practice, John Wiley \& Sons.

Meyers-Levy, Joan and Tybout, A. M. (1989), "Schema Congruity as a Basis for Product Evaluation," Journal of Consumer Research, 16(June), p39-54.

Nedungadi, Prakash and J. Wesley and Hutchinson (1985), "The Prototypicality of Brands: Relationships with Brand Awareness, Prefernce and Usage," in Advances in Consumer Research, Vol. 12, eds. Elizabeth C. Hirschmand and Morris B. Holbrook, Provo, UT: Association for Consumer Research, p498-503.

Park, C. W and Lessig, V. P(1981), "Familiarity and Its Impact on Consumer Decision Biases and Heuristics," Journal of Consumer Research, Vol. 8 (Sep), pp223-230. 
Ratneshwar, S., and Shocker, A. D(1991), "Substitution in Use and Role of Usage Context in Product Category Structures" Journal of Marketing Research, Vol. 28, August, p281-295.

Rosch, Eleanor(1978), Principles of Categorization in Cognition and Categorization, eds. Eleanor Rosch and Barbara B. Lloyd, Hillsdale, NJ:Erlbaum, .

Rosch, Eleanor and Mervis, C. B.(1975), "Family Resemblances: Studies in the Internal Structure of Categores," Cognitive Psychology, 7(Oct), p573-605.

Sandell, R. G. (1968), "Effects of Attitudinal and Situational Factors on Reported Choice Behavior", Journal of Marketing Research, vol. 4, August, p405-408.

Srivastava, R. K., Alpert, M. I. and Shocker, A. D. (1984) " A Customer-oriented Approach for Determining Market Structures" Journal of Marketing 48, Spring, p32-45.

, Leone, R. P. and Shocker, A. D. (1981), "Market Structure Analysis : Hierarchical Clustering of Products Based on Substitution-in-Use", Journal of Marketing, Vol. 45, Summer, p38-48.

Sujan, Mita and Christine Dekleva(1987), "Product Categorization and Inference Making: Some Implication for Comparative Adversing," Journal of Consumer Research, 14,(1Dec), 372-378.

Urban, G. L., Johnson, P. L. , and Hauser, J.R. (1984), "Testing Competitive Market Structures," Marketing Science, 3, 2, p83-112.

Ward, S. and Robertson, T. S.(1973), Consumer Behavior Research: Promise and Prospects, Consumer Behavior : Theoretical Sources, Englewood Cliffs: Prentice Hall. 